\title{
ПУБЛІЧНИЙ ВИСТУП ЯК РЕАЛІЗАЦІЯ ОРАТОРСЬКОЇ МАЙСТЕРНОСТІ
}

У статті визначено теоретичні засади публічного спілкування, що становить мету роботи. Актуальність проблеми статті визначається необхідністю засвоєння кожною особистістю, чия професійна зайнятість тісно пов 'язана з мовно-комунікативною діяльністю, понять і основних категорій наукового, педагогічного, офіційно-ділового, політичного дискурсу, що здійснюється на основі державної мови, має різні форми вияву. Досліджено, що зазначений тип мовної комунікації регулюється стратегіями і тактиками учасників, постає як синтез когнітивних, мовних, соціальних, психологічних, етичних, гендерних, етнічних чинників. Доведено, що ефективність спілкування сьогодні ставиться в однозначну залежність з ораторським мистецтвом комунікантів. Запропоновано комунікантам методику якісної підготовки до публічного виступу й виголошення промови.

Ключові слова: публічна комунікація, комунікативна лінгвістика, публічний виступ, ораторська майстерність, дискурс, когнітивні й мовні чинники, мовленнєві жанри, вербальні й невербальні засоби, засоби фасцинації, мовленнєвий етикет, комунікативна компетентність.

Gamova H. I. Public Speech as Realization of Oratory Skill. Based on the analysis of domestic and foreign scientific research into the basics of linguistic communication, the paper determines the theoretical principles of public speaking in all spheres of human activity: educational, scientific, political, legal, business, economic, etc., which suggests the objective of the present paper. The urgency of the problem explored in the paper is stipulated by the need for every educated person whose professional occupation is closely related to language and communicative activity to learn the notions and basic categories of scientific, pedagogical, official and business, and political discourse as a type of communication that is held on the basis of the official language, acquires different forms of manifestation (oral, written, paralingual etc.). It has been found that the said type of linguistic communication is regulated by the strategies and tactics of its participants; is brought to life as a synthesis of cognitive, linguistic, social, psychological, ethical, gender, ethnic factors; is specified by a particular range of questions; and results in forming a variety of speech genres: speeches, messages, reports at scientific conferences, political debates, business negotiations, discussions, interviews, briefings etc.

It has been proved that today the efficacy of communication is geared directly to the development of the oratory skills of communicants - to their ability to suggest ideas in a logical way, correctly, conclusively, and figuratively, that is with masterly skill. The skills of eloquence are developed in the course of rhetoric training, which helps to master the verified-by-experience system of techniques, means, figures and patterns intended to achieve the communication goal - a productive cooperation. The communicants have been suggested a methodology of a quality preparation for public speaking and making reports, mastering the speech techniques, verbal and non-verbal means of communication, skillful conducting of business conversations, negotiations, professional maintaining of their own views in debates and discussions, skillful delivery of university classes. The recommendations given will be useful for teachers, lawyers, journalists, managers, politicians, business people for whom the skills of communication and public speeches make up their professional qualification features, requiring the orator's perfect arrangement of speech, mastery of means of logical influence over the listeners, rhetoric expressive means, knowledge of language etiquette formulae. Thus, the speaker's oratory skills are expressed through their mastery of the oratory style, the manner in front of the audience, strategies of coping with anxiety, ability to give prompt answers, appeal to the opponent in a discussion or debate. 
Key words: public communication, communicative linguistics, public speech, oratory skill, discourse, cognitive and linguistic factors, speech genres, verbal and non-verbal means, means of fascination, speech etiquette, communicative competence.

\section{Ветуп}

Постановка проблеми. Однією з важливих складових у виробленні професійних компетенцій ділових людей нової генерації є культура ділової комунікації, яка передбачає високу майстерність спілкування, уміння будувати ділові відносини так, щоб досягти ефективності й мети у всіх видах і формах професійної діяльності. Для цього необхідно володіти державною мовою і іiї нормами, вміло використовувати все багатство вербальних, паралінгвальних, граматичних, стилістичних засобів української мови, досконало володіти фонаційно-кінетично-проксемічними засобами усного мовлення.

Ефективність спілкування в будь-якій сфері людської діяльності однозначно залежна й від ораторської майстерності учасників комунікації, тобто від їхнього вміння бути майстерним промовцем, логічно й змістовно подавати інформацію, доречно добирати мовні й виражальні (художні) засоби, будувати повідомлення чи репліку точно, виразно, переконливо й аргументовано, досконало знати вербальні й невербальні засоби мовного впливу і логічності, володіти культурою суперечки тощо. Вважаємо, що випрацювання актуальних на сьогодні якостей ділової людини дозволить їй стати органічним мовцем і виховати себе як публічного інтелектуала Української держави. Усе означене доводить актуальність указаної проблематики.

Аналіз останніх досліджень і публікацій з основ мовної комунікації представлено роботами вітчизняних і зарубіжних дослідників комунікативної лінгвістики Ф. Бацевича, Г. Гамової, С. Дорошенка, А. Загнітка, О. Сербенської, О. Селіванової, П. Редіна, Ф. Хмеля, І. Хоменко, Т. Чмут, О. Яшенкової, Дж. Остіна, Х. Грайса, Дж. Ліча, П. Сопера та ін.

Мета статті полягає в здійсненні цілісного науково-теоретичного аналізу закономірностей, складників, чинників мовної комунікативної діяльності, що здійснюється на базі державної мови, регулюється стратегіями учасників і реалізується в різних мовленнєвих жанрах.

\section{Методи та методики дослідження}

Методологічною й теоретичною основою статті є фундаментальні положення теорії інформації, теорії масової комунікації, теорії управління, а також надбання вітчизняних і зарубіжних учених з основ мовної комунікації та питань публічного спілкування.

У статті використано такі загальні методи дослідження: монографічний (під час опрацювання літературних джерел), порівняльного аналізу (для дослідження підходів, концепцій, розробок, присвячених засадам мовної комунікації), логіко-семантичний (для поглиблення понятійного апарату при визначенні основних складових публічної промови (виступу), абстрактнологічний (під час теоретичного узагальнення та формування висновків); а також спеціальні методи - ідеалізації, дискурс-аналізу, лінгвістичної абстракції та ін. 


\section{Результати та дискусії}

Сучасна ділова людина різної професійної приналежності є публічною особистістю, тому вона повинна оволодіти ораторською майстерністю: виголосити промову, конструктивно вести переговори, дискусії, виступати на міжнародних наукових конференціях, виробничих нарадах, давати інтерв’ю, вести політичні дебати тощо. Ораторські вміння виявляються не тільки в довершеному володінні мовою, мовленнєвою виразністю, яка полягає у використанні багатства мови, її виражальних засобів, що надають мовленню емоційності, образності, переконливості, побудові змістовної промови, а у й майстерному ії виголошенні. Для цього необхідно навчитися виступати з промовою, опанувати методику ораторського мистецтва, тобто оволодіти ораторським стилем, манерою триматися перед аудиторією, боротися з хвилюванням, уміти відповідати на запитання, апелювати опонентові по дискусії чи дебатах тощо (Бацевич, 2005; Гамова, 2014; Мацько, 2003).

Публічний виступ - це промова перед масовою аудиторією. Специфіку публічного виступу характеризують такі ознаки: ситуативність, безпосередній зв'язок зі слухачами, орієнтація на усне мовлення, використання разом з мовними й немовних засобів впливу на слухачів, попередня продуманість і підготовленість, монологічна форма й діалогічний характер, наявність колективного співбесідника - аудиторії, невимушеність. Крім того, зауважують дослідники публічного дискурсу, оратор повинен володіти всіма способами (каналами) впливу на слухача: звуковими (мовні й паралінгвальні (фонаційні) та візуальними (одяг, міміка, жести, поза) (Гамова, Редін, 2018).

Специфікою публічної промови (виступу) обумовлені труднощі, пов'язані з ії підготовкою й виголошенням: необхідність зацікавити велику кількість людей; відсутність прямої реакції слухачів; необхідність одночасно виголошувати промову й стежити за реакцією слухачів, щоб не втратити контакту з ними; необхідність чітко дотримуватися предмета обговорення; дотримуватися мовних норм; бути уважним до поставлених питань; відповідати особистісним якостям промовця (зовнішній культурі, морально-етичній, мовній культурі, культурі почуттів тощо).

Успіх публічного виступу багато в чому залежить від рівня професійної майстерності оратора, який (рівень) визначається низкою спеціальних умінь і навичок, тобто риторичними уміннями: підготовчими (уміння обрати тему, iii формулювання; дібрати й систематизувати теоретичний і практичний матеріал; створити текст відповідно до особливостей усного мовлення й специфіки аудиторії); уміннями складати план; мовленнєвими вміннями (висока мовленнєва культура, досконале володіння технікою і виразністю мовлення); соціально-комунікативними вміннями, в основі яких - здатність оратора встановлювати контакт зі слухачами, управляти аудиторією. Для цього він повинен уміти обирати відповідно до аудиторії форму спілкування; вживати різні способи привертання й підтримки уваги слухачів; етичними вміннями, що передбачає володіння загальною виконавчою культурою, дотриманням правил етикету. Це передусім передбачає: використання оратором відповідних форм привітань, звертань, інших етикетних формул; дотримання вимог 
до зовнішності; застосування відповідних жестів, міміки; установлення просторових відносин в аудиторії залежно від умов комунікації (Селіванова, 2011; Сопер, 2005, Хміль, 2004; Хоменко, 2001; Чмут, 2008).

Композиція промови. Для успішного публічного виступу недостатньо вивчити літературу з обраної теми, необхідно продумати побудову, структуру виступу, композицію. У теорії риторики розроблена універсальна композиційна схема - структура промови, спільна для всіх родів і жанрів красномовства, яка включає вступ, головну частину і висновки. Така схема композиції враховує правило «золотого перетину»: вступ і висновки за обсягом сумарно не повинні перевищувати одну третю всього тексту промови; «закон краю»: початок і кінець виступу запам'ятовуються краще, ніж його середина.

У вступі підкреслюється актуальність теми, значення її для даної аудиторії, коротко подається історія питання. Для привернення уваги слухачів рекомендується використовувати такі форми перших фраз перед вступом:

- комплімент на адресу слухачів;

- питання до аудиторіï;

- иікавий приклад з життя, історії;

- яскраві статистичні дані, факти;

- парадоксальні твердження;

- крилаті висловлювання політиків, громадських діячів, письменників, науковиів тощо.

У висновках рекомендується повторити основну думку промови, підбити підсумки сказаному.

Слід звернути увагу на недоліки вступу і висновків: численні вибачення оратора за свою недостатню підготовленість до виступу; відсутність зв'язку між вступом і висновками; відсутність зв'язку з основною частиною; натягнутість як наслідок порушення правила «золотого перетину».

У головній частині викладається основний матеріал, послідовно пояснюються висунуті положення, доводиться їх правильність. Структура головної частини: виклад, аргументація (доведення чи заперечення точки зору опонента). Мовними засобами логічності викладу виступають:

- показники послідовності підтем: по-перше, у першу чергу, з одного (iншого) боку, далі, крім того та ін.;

- показники наведення прикладів: наприклад, розглянемо (проаналізуємо) такий приклад, прикладом може бути та ін.;

- показники посилань на попереднє й наступне: раніше ми вже говорили..., необхідно зауважити..., детальніше розглянемо це питання в кінці та ін.;

- показники підсумку: таким чином, отже, значить, підбиваючи підсумки, зауважимо... та ін.

Комунікативна якість виразності промови тісно пов'язана з поняттям мовленнєвої виразності, яка відображає етап словесного оформлення тексту промови. Мовленнєва виразність - це використання лексичного багатства мови, його стилістичних можливостей, які надають мовленню образності, емоційності. 
Виражальні засоби, або засоби фасцинації (зачарування), - це засоби емоційного вербального впливу на слухачів при передаванні інформації, спрямовані на підвищення якості іiї сприймання шляхом впливу на емоційний стан і поведінку слухачів (Хміль, 2004).

Мова на всіх рівнях (фонетичному, лексичному, словотворчому, граматичному (морфологічному і синтаксичному), стилістичному містить експресивні категорії, які впливають на почуття, і всі ці категорії увіходять до складу виражальних засобів мови.

Звукова виразність мови пов'язана з естетичною оцінкою звуків: милозвучність, або звукова гармонія, - сукупність звуків, які зручні для вимови і приємні для слухача.

Вербальні засоби виразності (засоби фасцинації) мовлення оратора.

До виражальних засобів належать художні засоби виразності мовлення комуніканта. У комунікативній лінгвістиці для них є термін «засоби фасцинації» («фасцинація» в перекладі з англійської означає «зачарування»). Фасиинація - спеціально організований вербальний вплив при передаванні інформації, спрямований на підвищення якості сприймання інформації шляхом впливу на емоційний стан і поведінку комунікантів. Художні засоби, тобто засоби фасцинації, - продуктивний засіб усного ділового мовлення, особливо в обговореннях надважливих завдань на нарадах, переговорах, у дискусіях, полеміці, тобто в офіційно-діловому дискурсі.

Види художніх засобів виразності: тропи, мовні (стилістичні) фігури.

У своїх наукових розвідках з проблеми цільової організації й оптимізації управлінської діяльності працівників публічного управління Г. О. Гамова класифікувала й описала характерні ознаки засобів фасцинації ділового спілкування (Гамова, 2014).

Тропи. Троп ( з гр. означає зворот, образ) - це художній зворот, варіант уживання слів, словосполучень і фраз у переносному, тобто образному значенні. В основі тропів лежить образ, порівняння. Це епітети, метафори, уособлення, персоніфікація, алегорія, символ, метонімія, синекдоха, гіпербола тощо.

Enimem - це образне визначення, що передає ставлення промовця до предмета: гарячий, розпечений час, гаряча підтримка, гарячий лід, холодне серце, блакитна кров, хвилююча зустріч, голуба мрія, залізна воля, дешевий автоpumem.

Метафору теж можна назвати прихованим порівнянням. Це перенесення значення (ознаки) слова як знака предмета на інший за принципом подібності. Вдалі метафори дозволяють краще зрозуміти суть явища, зробити їх зримими: наріжний камінь, камінь спотикання, своя рука владика, пекторалі поета (прекрасна поезія), чаша терпіння, печать мовчання, випити гірку чашу.

Метонімія - слово чи словосполучення, що замінює назву предмета на основі суміжності (певного зв'язку між ними) у просторі і часі: активна аудиторія (студенти, слухачі), все вирішує гаманеиь (тобто гроші).

Алегорія - це зображення абстрактного поняття чи явища через конкретний образ. Алегорія однозначна, вона схожа на емблему: тартюф 
- алегорія лицемірства; донкіхот - алегорія лицарства; донжуан - алегорія сластолюбия.

Оказіоналізми - авторські неологізми, що становлять індивідуальні авторські новотвори, складені з двох-трьох семантично далеких коренів. Таким поєднанням створюється нове сатиричне або іронічно-дошкульне значення. Наприклад, український письменник-полеміст кінця 16 ст. І. Вишенський - творець таких оказіоналізмів: богочревці, скачомудрець, кровоєд, свиноєд, куроєд, скотоєд, маслоєд; периноспал, тєлолюбець, перцолюбець, сладколюбець, чревобісник; млекопий та ін. (Мацько, 2003).

Стилістичні (мовні), або риторичні фігури. Це мовні звороти, синтаксичні конструкції, що використовуються для посилення емоційного сприйняття інформації.

Однією з ознак риторичної майстерності оратора є вміння, залежно від ситуації, «грати» словом, тобто комбінувати слова так, щоб вислів (а це синтаксично - речення) вразив слухача. До мовних фігур науковці відносять: риторичний оклик, риторичне запитання, інверсію, ампліфікацію, етичні антитези, іронію, хіазм каламбури, парадокси тощо (Гамова, 2014).

Риторичний оклик - емоційне твердження чи заперечення з метою привернення уваги: O часи! $O$ звичаї! (Цицерон); риторичне запитання - Чи справді сміється той, хто сміється останнім?; інверсія - розміщення слів в особливому порядку, що порушує прямий порядок: Працювати вони не хочуть, а жити хочуть добре; Легко вірити в Бога, а в людину повірити ви пробували?(Пономарів, 1999).

Хіазм - порядок слів, при якому спостерігається «перехрещення» слів (як літера X): Одні живуть, аби їсти, інші їять, аби жити; Люди поділяються на праведників, що вважають себе грішниками, та грішників, що вважають себе праведниками (Паскаль); Колись були Орфеї, а тепер корифеї, а як же він став корифеєм, як не був Орфеєм (Л. Костенко).

Іронія (прихована насмішка) - фігура, з допомогою якої авторові легко натякнути на своє ставлення до об'єкта; дати зрозуміти, що оратор критично ставиться до зображуваної ним людини чи явища, хоча прямо цього не висловлює: Кожсному своє, але іноді так хочеться чужсого; Мені подобається, коли без церемоній, але з подарунками; Мало мати сумління, треба, шоб воно ще й мучило; Коли у Вас заговорить сумління, не забувайте йому нагадати про регламент; Проблема століття не вічний двигун, а вічне пальне; Якщо істина на дні бокала, то чому же тоді вона говорить устами дитини?! (Пономарів, 1999).

Каламбур - це гра такими лексичними явищами, як омонімія чи багатозначність: Як усі оратори, що ставлять собі за мету вичерпати тему, він вичерпав терпіння слухачів.

Парадокс - неочікуване судження, висновок, що різко розходиться із загальноприйнятою думкою чи логікою попереднього висловлювання: Не заводьте дітей!. Ви їм даруєте життя, вони вам - смерть. Ви їх народжуєте на світ, вони вас зживають зі світу (Бальзак).

Ампліфікація - перелік з метою емоційного нагнітання: Я стверджую, що в усій Сицилії, такій багатій, такій давній провінції, в якій так багато міст 
і таких багатих домів, не було жодної срібної, жодної корінфської або делонської вази, ні одного дорогоцінного каменя чи перлини..., яких би Гай Веррес не розшукав, не роздивився $i$, якщо вони подобалися йому, не забрав собі (Цицерон).

Етичні антитези - зіставлення протилежних явищ, образів для посилення враження: Адже на нашій стороні бореться почуття честі, на тій нахабство; тут сором'язливість, там - розбещеність; тут - вірність, там - злочин; тут - чесне ім 'я, там ганьба... (Цицерон) (Гамова, 2014).

Для привернення уваги слухачів, створення відповідного психологічного настрою, надання висловлюванню більшої емоційності та експресивності використовують прийоми пожвавлення промови: прислів'я і приказки, фразеологізми, афоризми, крилаті висловлювання визначних людей, цитати тощо.

Основною вимогою до використання риторичних засобів виразності мовлення оратора є доречність і комунікативна доцільність.

\section{Невербальні (позамовні, паравербальні) засоби емоційного впливу}

Вони є своєрідними каналами інформації, інтерпретують візуальну картину про партнера чи оратора. Дії, рухи, зовнішність, тактильний контакт, орієнтація, тобто просторове положення партнерів один щодо одного, поза тіла, вираз обличчя, жести несуть інформацію самі по собі. Будучи супроводжувальними вербальним засобам, позамовні засоби ділового спілкування визначають його ефективність.

Науковці розрізняють три види невербальних засобів:

- фонаційні (тембр, сила, висота голосу, мелодика, темп мовлення, пауза, особливості вимови звуків);

- кінетичні (жести, поза, міміка, зовнішній вигляд людини, погляд);

- проксемічні (відстань між мовцями, тактильний контакт, розташування робочих місць тощо) ( Загнітко, 2014; Сербенська, 2004).

Фонаційні, або акустичні, засоби (тональність голосу, мелодика, тембр, meмn). Вони створюють енергетику мовлення, експресивність, тональну варіативність, виразність, переконаність, упевненість мовця. Єдність манери поводження й мовлення захоплює слухача.

Teмn мовлення: жвава манера говорити, швидкий темп мовлення свідчить про імпульсивність співрозмовника, його впевненість у собі; спокійна повільна манера вказує на незворушність, розважливість, виваженість; помітні коливання швидкості мовлення сигналізують про невпевненість, збудженість людини. Гучність мовлення: гучний голос вказує на щирість, радість чи обурення або є ознакою зарозумілості й самозадоволення. Неголосне мовлення характеризує стриманих, скромних, тактовних людей, а також слабких.

Тембр і мелодика голосу є засобами жанрового й стилістичного вираження текстів промов:

Tембр золотий - мажор (урочистий, величний, гордий, радісний, тон захоплення, натхнення). Він характерний для урочистих промов.

Teмбр срібний - також мажор (світлий, елегійний, радісний, милий, граційний, інтимний, передає почуття щастя, задоволення, радості). 
Тембр мідний - мінор (металевий голос, енергійний, важкий). Це тон туги, обурення, суворої похмурості, викривальності, гнівної інвективи. Він характерний для політичних промов, судових, агітаційних, мітингових.

Тембр оксамитовий - мінорний м'який, сердечний, майже завжди журливий, часто мрійний. У ньому тихий жаль, журба, туга без відчаю.

Bucoma голосу: фальцет найчастіше властивий людині, у якої мислення й мовлення є значною мірою інтелектуальними продуктами; низький грудний голос свідчить про те, що мислення й мовлення супроводжуються підвищеною емоційністю, що вони природні, а не штучні; високий пронизливий голос - ознака страху й хвилювання; низький тон голосу - це розслабленість, спокій і гідність (Сербенська, 2004).

Кінетичні. Психологи зазначають, що якісна промова сприймається зоровим шляхом. Тому ораторові важливо приділяти значну увагу своїй зовнішності, бо сила першого враження дуже важлива в будь-якій ситуації.

Традиційно науковці виділяють такі невербальні візуальні засоби впливу: зовнішність і способи іï оформлення, манери, поза, жести (Хоменко, 2001).

Зовнішність і способи її оформлення (одяг, зачіска, косметика, прикраси) - це візитівка оратора, засіб його самовираження й одночасно одна з форм психологічного впливу на аудиторію.

Вимоги до зовнішності оратора:

1. Зовнішність повинна відповідати його особистості, ситуації. Це слід враховувати при виборі типу костюма (вечірній, діловий, спортивний).

2. Охайність, доречність і доцільність у виборі прикрас.

3. Коректність - краща риса в зовнішності оратора. Це значить, що своєю зовнішністю він не повинен викликати здивування, роздратування чи заздрість аудиторії.

4. Особливу увагу необхідно приділяти кольоровій гамі костюма, вибираючи ту, яка відповідає вимогам комунікативної ситуації.

Манери. Знання хороших манер, зовнішніх форм поведінки, дозволяє почувати себе впевнено в будь-якій ситуації. Вимоги до хороших манер:

1. Манери, поведінка оратора повинні визначатися доброзичливістю, повагою до аудиторії. Оратор повинен уміти створити доброзичливу, але разом з тим ділову атмосферу.

2. Тональність виступу визначається типом промови, обставинами спілкування. Вона може бути спокійною, схвильованою, іронічною, але обов'язково доброзичливою і діловою.

3. Погане самопочуття, настрій промовця не повинні проявлятися в аудиторії. Упевненість, відсутність нервозності, органічність - обов'язкові якості хороших ораторських манер.

4. Хороші манери передбачають наявність зорового контакту оратора зі слухачами. При цьому велика увага приділяється міміці, погляду, виразу його обличчя.

Поза. Важливе значення має поза оратора - положення тіла в просторі, манера стояти. Правильною для оратора вважається така манера стояння: 
ноги злегка розставлені залежно від зросту, одна нога трішки виступає вперед. Спина пряма, у плечах і руках немає напруження.

Проксемічні (простір). Важливо уміти правильно організувати простір в аудиторії. Слід пам’ятати, що зона публічного спілкування складає 3-6 м.

Жести. Міміка. Значення мають і жести - динамічні рухи якої-небудь частини тіла, що мають комунікативну направленість. Важливо пам'ятати, що вони мають національну, соціальну, професійну й вікову специфіку (Хоменко, 2001).

\section{Висновки}

Доведено, що майстерність публічної промови (виступу) вимагає від оратора довершеної композиції промови, володіння ним засобами логічного впливу, риторичними засобами виразності, які впливають на емоційноекспресивний стан слухачів, знання формул мовного етикету.

Отже, випрацювання означених кваліфікаційних якостей оратора в умовах сьогодення дозволить діловій людині стати органічним мовцем і публічним інтелектуалом Української держави та ефективно реалізовувати у своїй діяльності функціональні обов’язки.

\section{ЛІТЕРАТУРА}

1. Бацевич Ф. Лінгвістична генологія: проблеми і перспективи: монографія. Львів: ПАІС, 2005. 264 с. 2. Гамова Г. І. Ораторське мистецтво : навч. посібн. 3-тє вид. Харків : Вид-во ХарРІ НАДУ «Магістр», 2014. С. 168. 3. Гамова Г. І., Редін П. О. Публічний дискурс. Електронний навчальний посібник до дистанційного курсу. Харків, 2018. URL: http://kbuapa.kharkov.ua/prometeus/resources/PD/index.html. 4. Дорошенко C. I. Основи культури і техніки усного мовлення: навч. посіб. Харків: ОВС, 2002. 144 с. 5. Загнітко А. П., Данилюк І. Г. Українське ділове мовлення: професійне і непрофесійне спілкування. Донецьк : ТОВ ВКФ “БАО”, 2004. 480 с. 6. Мацько Л. І., Мацько О. О. Риторика: навч. посіб. Київ: Вища школа, 2003. 311 с. 7. Пономарів О. Культура слова: Мовностилістичні поради : навч. посіб. Київ: Либідь, 1999. 240 с. 8. Селіванова О. О. Основи теорії мовної комунікації. Черкаси, 2011. 348 с. 9. Сербенська О. А. Культура усного мовлення. Практикум : навч. посіб. Київ, 2004. 216 с. 10. Сопер П. Основы искусства речи. Книга о науке убеждать. Москва, 2005. 324 с. 11. Хміль Ф. І. Ділове спілкування : навч. посіб. Київ : Академвидав, 2004. 279 с. 12. Хоменко І. В. Еристика: мистецтво полеміки: навч. посіб. Київ: Юрінком Інтер, 2001. 192 с. 13. Яшенкова О. В. Основи теорії мовної комунікації: навч. посіб. Київ: Академія, 2010. 309 с.

\section{REFERENCES}

1. Batsevych, F. (2005). Linhvistychna henolohiia: problemy i perspektyvy: monohrafiia [Linguistic genology: problems and prospects]. L'viv [in Ukrainian]. 2. Hamova, H. I. (2014). Orators'ke mystetstvo [Public speaking ]. Kharkiv [in Ukrainian]. 3. Hamova, H. I., Redin P.O. (2018). Publichnyj dyskurs. Elektronnyj navchal'nyj posibnyk do dystantsijnoho kursu [Public Discourse]. Kharkiv [in Ukrainian]. 4. Doroshenko, S. I. (2002). Osnovy kul'tury $i$ tekhniky usnoho movlennia [Fundamentals of Culture and Techniques of Oral Speech]. Kharkiv [in Ukrainian]. 5. Zahnitko, A. P. (2004). Ukrains'ke dilove movlennia: profesijne $i$ neprofesijne spilkuvannia [Ukrainian business broadcasting: professional and unprofessional 
communication]. Donets'k [in Ukrainian]. 6. Mats'ko, L. I. (2003). Rytoryka [Rhetoric]. Kyiv [in Ukrainian]. 7. Ponomariv, O. (1999). Kul'tura slova: Movnostylistychni porady [Culture of the word: Language-linguistic advice]. Kyiv [in Ukrainian]. 8. Selivanova, O. O. (2011). Osnovy teorii movnoi komunikatsii [Fundamentals of the theory of linguistic communication]. Cherkasy [in Ukrainian]. 9. Serbens'ka, O. A (2004). Kul'tura usnoho movlennia [Culture of Oral Speech]. Kyiv [in Ukrainian]. 10. Soper, P. (2005). Osnovy yskusstva rechy. Knyha o nauke ubezhdat' [Basics of speech art. A book about science to convince]. Moskva [in Russian]. 11. Khmil', F. I. (2004). Dilove spilkuvannia [Business communication]. Kyiv [in Ukrainian]. 12. Khomenko, I. V. (2001). Erystyka: mystetstvo polemiky [Eristhic: the art of polemics]. Kyiv [in Ukrainian]. 13. Yashenkova, O. V. (2010). Osnovy teorii movnoi komunikatsii [Fundamentals of the theory of linguistic communication]. Kyiv [in Ukrainian].

Гамова Ганна Іванівна - кандидат філологічних наук, доцент, професор кафедри української мови Харківського регіонального інститут державного управління Національної академії державного управління при Президентові України; просп. Московський, 75, Харків, 61000, Україна.

Tel.: +38-050-904-79-48

E-mail: ukr.mova30@gmail.com

https://orcid.org/0000-0001-7905-0518

Gamova Hanna Ivanivna - PhD in Philology, Associate Professor, Ukrainian Language Department, Kharkiv Regional Institute of Public Administration of the National Academy for Public Administration under the President of Ukraine; Moskovskyi Av., 75, Kharkiv, 61000, Ukraine.

Надійшла до редакції 22 березня 2019 року 